\title{
Dynamics of viral hemorrhagic septicemia, viral erythrocytic necrosis and ichthyophoniasis in confined juvenile Pacific herring Clupea pallasii
}

\author{
Paul Hershberger ${ }^{1, *}$, Alexandra Hart ${ }^{2,3}$, Jake Gregg ${ }^{1}$, Nancy Elder ${ }^{1}$, James Winton ${ }^{3}$ \\ ${ }^{1}$ Western Fisheries Research Center, Marrowstone Marine Field Station United States Geological Survey, \\ Biological Resources Discipline, 616 Marrowstone Point Road, Nordland, Washington 98358, USA \\ ${ }^{2}$ Department of Biology, University of Washington, Box 351800, Seattle, Washington 98195, USA \\ ${ }^{3}$ Western Fisheries Research Center, United States Geological Survey, Biological Resources Discipline, 6505 NE $65^{\text {th }}$ Street, \\ Seattle, Washington 98115, USA
}

\begin{abstract}
Capture of wild, juvenile herring Clupea pallasii from Puget Sound (Washington, USA) and confinement in laboratory tanks resulted in outbreaks of viral hemorrhagic septicemia (VHS), viral erythrocytic necrosis (VEN) and ichthyophoniasis; however, the timing and progression of the 3 diseases differed. The VHS epidemic occurred first, characterized by an initially low infection prevalence that increased quickly with confinement time, peaking at 93 to $98 \%$ after confinement for $6 \mathrm{~d}$, then decreasing to negligible levels after $20 \mathrm{~d}$. The VHS outbreak was followed by a VEN epidemic that, within $12 \mathrm{~d}$ of confinement, progressed from undetectable levels to $100 \%$ infection prevalence with $>90 \%$ of erythrocytes demonstrating inclusions. The VEN epidemic persisted for $54 \mathrm{~d}$, after which the study was terminated, and was characterized by severe blood dyscrasias including reduction of mean hematocrit from 42 to $6 \%$ and replacement of mature erythrocytes with circulating erythroblasts and ghost cells. All fish with ichthyophoniasis at capture died within the first 3 wk of confinement, probably as a result of the multiple stressors associated with capture, transport, confinement, and progression of concomitant viral diseases. The results illustrate the differences in disease ecology and possible synergistic effects of pathogens affecting marine fish and highlight the difficulty in ascribing a single causation to outbreaks of disease among populations of wild fishes.
\end{abstract}

KEY WORDS: Disease · Fish • Viral hemorrhagic septicemia • Viral erythrocytic necrosis · Ichthyophonus $\cdot$ Pacific herring $\cdot$ Wild fish

Resale or republication not permitted without written consent of the publisher

\section{INTRODUCTION}

Awareness of the effects of emerging diseases on fish and wildlife has risen over the past several years; however, our understanding of the effects of disease on marine species remains limited (Harvell et al. 2004), probably because the effects typically go unnoticed and causation is difficult to demonstrate (Scott 1988). Our understanding of the effects of disease in populations of wild marine fishes is further impaired by the frequent presence of multiple pathogens and the unavailability of immunologically naïve hosts neces- sary to fulfill Koch's postulates. For example, the biomass of Pacific herring Clupea pallasii in Prince William Sound decreased from 98 million $\mathrm{kg}$ in 1992 to <20 million kg in 1993 (Marty et al. 1998). Although infectious disease was proposed as a contributing factor, causation was confounded by identification of multiple etiological agents, including viral hemorrhagic septicemia virus, lymphocystis virus, Ichthyophonus hoferi, myxosporeans, coccidians, trematodes and cestodes (Marty et al. 1998). In southern Australia, 2 of the largest mass mortality events ever reported to involve fish were characterized by declines in sardine 
Sardinops sagax biomass from 165000 to 37000 tonnes in 1995 and from 147000 to 36000 tonnes in 1998 (Jones et al. 1997, Whittington et al. 1997, Gaughan et al. 2000, Ward et al. 2001). Although mortality was associated with herpesvirus-like particles in the gills of affected sardines (Hyatt et al. 1997, Jones et al. 1997, Gaughan et al. 2000), transmission studies and attempts to fulfill Koch's postulates were unsuccessful (Bernoth 2002).

In Puget Sound, Washington (USA), several pathogenic agents, including viral hemorrhagic septicemia virus (Hershberger et al. 1999, Kocan et al. 2001), erythrocytic necrosis virus (MacMillan \& Mulcahy 1979) and Ichthyophonus hoferi (Kocan et al. 1999, Hershberger et al. 2002) are enzootic in populations of Pacific herring Clupea pallasii. Viral hemorrhagic septicemia virus (VHSV) is grouped with several other commercially and ecologically important fish viruses in the Novirhabdovirus genus of the family Rhabdoviridae (Walker et al. 2000). North American isolates belong to VHSV Genogroup IV and have been recovered almost exclusively from marine or anadromous fishes, similar to reports for the European Genogroups Ib, II and III (Snow et al. 2004). Juvenile and newly recruited Pacific herring are highly susceptible to VHSV (Kocan et al. 1997), and application of nominal stressors to wild cohorts, including capture and confinement, is often sufficient to initiate disease outbreaks (Hershberger et al. 1999, Kocan et al. 2001). Similarly, natural stressors occurring in situations where the virus is endemic among wild populations of herring may contribute to epidemics that have been reported in the eastern North Pacific (Traxler et al. 1999, Hedrick et al. 2003).

Viral erythrocytic necrosis (VEN) is characterized by the presence of viroplasmic inclusion bodies located within the cytoplasm of affected erythrocytes (reviewed in Dannevig \& Thorud 1999). Although the etiology is not completely understood, primarily because of the refractory nature of established cell lines to infection by the causative agent (Evelyn \& Traxler 1978), it is likely to be associated with a presumed iridovirus, referred to as erythrocytic necrosis virus (ENV). In Puget Sound and the eastern North Pacific, the condition frequently occurs in Pacific herring Clupea pallasii (MacMillan \& Mulcahy 1979), where it has been associated with natural mortality (Meyers et al. 1986).

The genus Ichthyophonus is a member of the Mesomycetozoea, a monophyletic class of protozoans that includes several other pathogenic organisms (Ragan et al. 1996, Herr et al. 1999, reviewed in Mendoza et al. 2002). Currently I. hoferi (reviewed in McVicar 1999) and I. irregularis (Rand et al. 2000) are the only 2 recognized species in the genus, but other species have probably been grouped with I. hoferi based on the plasticity of morphological characteristics (McVicar 1999). Additional molecular phylogenetic studies are necessary to better understand the relatedness of $I$. hoferi isolates (Criscione et al. 2002, Halos et al. 2005); therefore, the organism will be referred to generically as Ichthyophonus hereafter in this manuscript. From 1898 through the mid-1950s, 6 major Ichthyophonus-related epidemics were described in Atlantic herring Clupea harengus from the western North Atlantic (Sindermann 1990, McVicar 1999). More recently, a massive Ichthyophonusrelated epidemic killed an estimated 300 million Atlantic herring in marine waters around Sweden and Denmark during the early 1990s (Rahimian \& Thulin 1996), and epidemiological data implicate Ichthyophonus as a primary factor responsible for mortality in wild Pacific herring C. pallasii from estuarine waters of Washington State (Hershberger et al. 2002).

One means to address the difficulties encountered with investigating the effects of disease on wild fish populations is to observe outbreaks in cohorts that are collected from the wild and confined to laboratory tanks. Although this approach introduces factors that may not occur in free-ranging populations, it provides an opportunity to observe disease dynamics resulting from natural infections with multiple pathogens. Here, we describe the comparative disease dynamics resulting from naturally-acquired infections with VHSV, ENV and Ichthyophonus in wild, juvenile herring held in marine aquaria.

\section{MATERIALS AND METHODS}

Collection of fish. Juvenile Age 0 Pacific herring Clupea pallasii were collected by dip net from 2 predator-corralled aggregations (bait balls) in Admiralty Inlet (Puget Sound, Washington) on July 30, 2003. Herring from each bait ball were transported alive to the Marrowstone Marine Station, and separated into 3 replicate 2751 tanks supplied with sand-filtered, UVtreated seawater. Herring from the first bait ball (mean fork length $=60 \mathrm{~mm}, \mathrm{SD}=5 \mathrm{~mm}$; mean mass $=1.8 \mathrm{~g}$, $\mathrm{SD}=0.5 \mathrm{~g} ; \mathrm{n}=30$ ) were loaded at 187 to 235 fish $\operatorname{tank}^{-1}$, and 10 fish $\mathrm{d}^{-1}$ were sampled from each tank 1,6, 12 and $20 \mathrm{~d}$ post capture. Herring from the second bait ball (mean fork length $=64 \mathrm{~mm}, \mathrm{SD}=5 \mathrm{~mm}$; mean mass $=2.2 \mathrm{~g}, \mathrm{SD}=0.7 \mathrm{~g} ; \mathrm{n}=30$ ) were loaded at

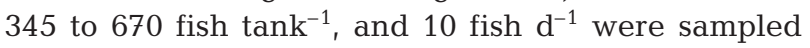
from each tank 1, 6, 12, 20, 28, 41 and 54 d post capture. Confined fish were fed daily with Cyclopeze ${ }^{\mathrm{TM}}$ (Argent Laboratories, Redmond, WA, USA). Dead and moribund individuals were sampled from all tanks as they appeared. 
Infection assays. Sampled fish were euthanized in $1 \mathrm{mg} \mathrm{ml}^{-1}$ tricaine methane sulfonate (MS 222) and screened for prevalence and intensity of VEN, VHS and ichthyophoniasis. For VEN, blood films were made from a severed caudal peduncle, air dried, fixed in $100 \%$ methanol, and stained with $7.5 \%$ Giemsa in phosphate buffer ( $\mathrm{pH}$ 6.9). The prevalence and intensity of ENV infections were determined by examining 200 blood cells under oil immersion at 1000× magnification for presence of intracytoplasmic inclusions (Fig. 1). Mean diameter of the cytoplasmic inclusions was measured with a micrometer $(n=300)$. Differential blood cell counts $(n=200)$, including mature erythrocytes, circulating erythroblasts, and leukocytes, were recorded from all blood films. Additional blood from each sampled fish was collected in heparinized capillary tubes and centrifuged for determination of hematocrit.

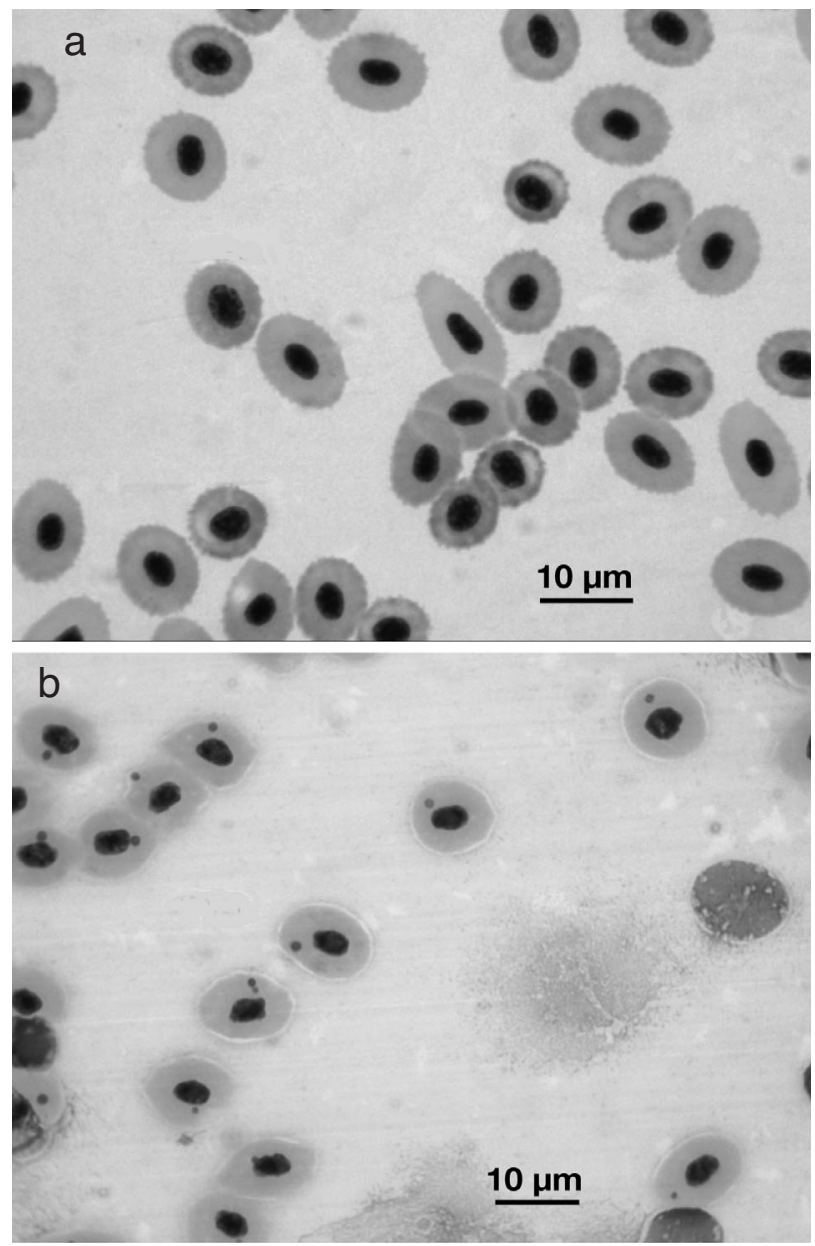

Fig. 1. Clupea pallasii. Giemsa-stained blood films from (a) laboratory-reared VEN-negative herring, demonstrating normal, healthy erythrocytes, and (b) confined, wild herring, demonstrating heavy infection with VEN (note inclusion bodies in cytoplasm of affected erythrocytes and presence of erythrocytic ghost cells)
Gross ichthyophoniasis was identified by the presence of black, melanophorous ulcers on the skin and/or white nodular lesions on internal organs. Ichthyophonus infection was confirmed by explant culture of heart tissues in Tris-buffered Eagle's minimum essential medium (MEM) containing 5\% fetal bovine serum, $100 \mathrm{IU} \mathrm{ml} \mathrm{m}^{-1}$ penicillin, $100 \mu \mathrm{g} \mathrm{ml} \mathrm{m}^{-1}$ streptomycin and $100 \mu \mathrm{g} \mathrm{ml}^{-1}$ gentamycin. Cultures were incubated at $12^{\circ} \mathrm{C}$ and examined microscopically ( $40 \times$ magnification) for presence of Ichthyophonus after $7 \mathrm{~d}$, with a final examination after $14 \mathrm{~d}$ if not already deemed positive.

Prevalence and intensity of VHSV infections were determined by plaque assay (Batts \& Winton 1989). Briefly, whole herring bodies (minus head, tail and heart) were homogenized in Tris-buffered Eagle's MEM containing $100 \mathrm{IU} \mathrm{ml}^{-1}$ penicillin, $100 \mathrm{\mu g} \mathrm{ml}^{-1}$ streptomycin, $100 \mathrm{\mu g} \mathrm{ml}^{-1}$ gentamycin, and $2.5 \mathrm{\mu g} \mathrm{ml}^{-1}$ amphotericin B. Serial 10-fold dilutions of the homogenates were plated on monolayer cultures of epithelioma papulosum cyprini (EPC) cells pretreated with polyethylene glycol, overlayed with methylcellulose, incubated at $15^{\circ} \mathrm{C}$ for $7 \mathrm{~d}$, and fixed/stained with a mixture of formalin and crystal violet. Virus titers were expressed as plaque forming units (pfu) $\mathrm{g}^{-1}$ tissue. Isolated virus from 15 infected fish was confirmed as VHSV using the polymerase chain reaction and VHSV-specific primers (Einer-Jensen et al. 1995). Fish were considered diseased with VHS when whole body tissue titers exceeded $10^{4} \mathrm{pfu} \mathrm{g}^{-1}$.

Challenge of pathogen-free herring. To confirm that erythrocytic inclusions were not a sign of late stage VHS in recovering individuals, specific-pathogen-free (SPF) herring were challenged with VHSV, and blood from the survivors was screened for erythrocytic inclusion bodies. To produce SPF test individuals, naturally spawned herring eggs adhering to submerged macrophytes were collected from Discovery Bay (Straight of Juan de Fuca, Washington) and transferred to laboratory tanks, supplied with double sand-filtered, particle-filtered, and double ultraviolet irradiated seawater, at the Marrowstone Marine Station. After hatching, larvae were fed a combination of laboratory-reared rotifers Brachionus plicatilis and recently-hatched Artemia sp. enriched with Super Selco ${ }^{\circledR}$ (INVE Aquaculture), Protein HUFA (Salt Creek), and Advanta Excel Feed (Aquatic Ecosystems). After approximately $60 \mathrm{~d}$, larvae were weaned to frozen Cyclopeze ${ }^{\mathrm{TM}}$. Larvae metamorphosed to juveniles 70 to $90 \mathrm{~d}$ posthatch, and were maintained on Cyclopeze ${ }^{\mathrm{TM}}$ until completion of these studies.

At 89 d post-hatch, 40 SPF juvenile herring were exposed to an isolate of VHSV (North American strain, Genogroup IV, Isolate No. 99-292 supplied by Garth Traxler) obtained in 1999 from Atlantic salmon Salmo salar cultured near Vancouver Island, Canada. The 
SPF juvenile herring were infected by waterborne exposure to $4220 \mathrm{pfu} \mathrm{ml}^{-1}$ in aquarium water for $1 \mathrm{~h}$, transferred to flow-through aquaria supplied with sand-filtered, UV-irradiated seawater, and monitored daily for mortality. Control cohorts $(\mathrm{n}=40)$ were exposed to Hanks' buffered saline solution (HBSS), transferred to a separate tank, and observed similarly. Dead and moribund fish were sampled from each tank as they appeared. Surviving herring were euthanized with an overdose of MS-222 after $22 \mathrm{~d}$ and sampled for the presence of erythrocytic inclusion bodies. Blood films were prepared and processed as described above.

Electron microscopy of erythrocytic inclusions. Transmission electron micrographs of blood cells were prepared from fish demonstrating severe VEN. Heavily infected fish were obtained by capturing an additional 345 juvenile herring by dip net from a bait ball in Admiralty Inlet on July 1, 2004, and transporting them to a 2751 tank supplied with flow-through seawater, where they underwent natural VHS and VEN epidemics similar to those described in the 2003 studies. Dead and moribund fish were collected from the tank daily. After $21 \mathrm{~d}$ of laboratory confinement, 15 herring were euthanized by an overdose of MS-222 and blood films were screened for VEN as described previously. Additional blood from all euthanized fish was drawn in heparinized capillary tubes, fixed in $4 \%$ glutaraldehyde (diluted with one-third strength seawater) for $1 \mathrm{~h}$, washed 3 times in one-third seawater, then post-fixed in $1 \%$ osmium tetroxide. Fixed blood samples corresponding to heavily infected blood films were then processed for transmission electron microscopy (Bozzola \& Russell 1992) and visualized with a Hitachi H-7100 transmission electron microscope.

\section{RESULTS}

\section{Dynamics of VHS, VEN and ichthyophoniasis}

Laboratory confinement of wild, juvenile herring resulted in rapid progression of a VHS epidemic (Fig. 2), characterized by an initially low disease prevalence that increased quickly, peaking at 93 to $98 \%$ after confinement for $6 \mathrm{~d}$. Prevalence of VHS remained at 84 to $91 \%$ through $12 \mathrm{~d}$, before eventually dropping to negligible levels. Median VHSV tissue titers responded similarly, increasing with confinement time from $3 \times 10^{3} \mathrm{pfu} \mathrm{g}^{-1}$ after $1 \mathrm{~d}$ to $3.6 \times 10^{6} \mathrm{pfu} \mathrm{g}^{-1}$ after $6 \mathrm{~d}$, then decreasing to $1.4 \times 10^{6}$, pfu g ${ }^{-1}$ after $12 \mathrm{~d}$, $4 \times 10^{2}$ pfu g $^{-1}$ after $20 \mathrm{~d}$, and 0 pfu g $^{-1}$ thereafter.

An outbreak of VEN followed the VHS epidemic and persisted through a period of $54 \mathrm{~d}$ at which time the study was terminated (Fig. 2). Mean prevalence of ery-

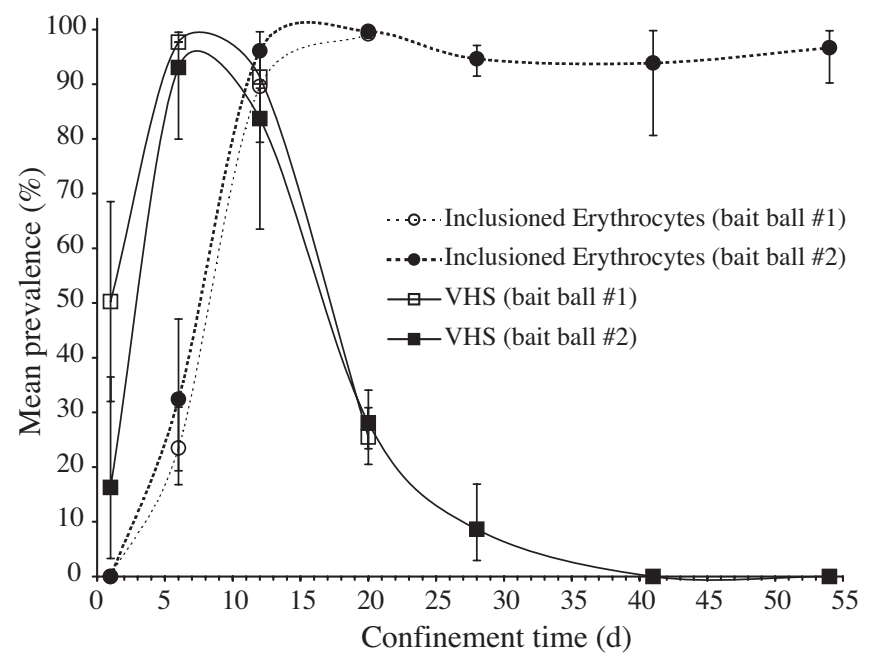

Fig. 2. Clupea pallasii. Progression of VHS and VEN in confined herring. Fish were considered diseased with VHS when tissue titers exceeded $10^{4} \mathrm{pfu} \mathrm{g}^{-1}$. VEN inclusions were detected in erythrocytes of all fish from Day 6 until end of study. Data represent proportions corresponding to means of arcsine-transformed prevalence in 3 replicate tanks; prevalence in each replicate was determined by sampling 10 fish $\operatorname{tank}^{-1}$ on each sampling date. (Means $\pm 2 \mathrm{SD} ; 95 \%$ confidence intervals)

throcytes bearing inclusions was $0 \%$ at $1 \mathrm{~d}$, but increased to $23-32 \%$ after $6 \mathrm{~d}$ and $90-96 \%$ after $12 \mathrm{~d}$. High levels of VEN, characterized by cytoplasmic inclusions appearing in $>90 \%$ of erythrocytes, persisted through $54 \mathrm{~d}$, at which time the study was terminated. Intraerythrocytic inclusions occurred in both mature and immature erythrocytes and averaged $1.56 \mu \mathrm{m}$ in diameter $(\mathrm{n}=300, \mathrm{SD}=0.60)$.

Blood changes associated with the viral epidemics included decreased numbers of cells in circulation and altered cell assemblages. Mean hematocrit decreased steadily with increasing confinement time from 44 to $45 \%$ at $1 \mathrm{~d}$ to $6 \%$ at $54 \mathrm{~d}$, when the study was terminated (Fig. 3). Anemia in fish that survived for $54 \mathrm{~d}$ was further characterized by pale, white gills and was associated with lethargic swimming behavior. Prevalence of circulating erythroblasts declined from $6-9 \%$ at $1 \mathrm{~d}$ to $1-2 \%$ after $6 \mathrm{~d}$, and then increased steadily until the end of the study, at which time $78 \%$ of all circulating blood cells were erythroblasts (Fig. 3). Throughout this period a large proportion of erythrocytic ghost cells appeared in circulation, probably representing the vanishing population of mature erythrocytes that were overwhelmed by ENV replication.

Heavy mortality during the first week of captivity was not enumerated because it is likely to have resulted from the combined effects of capture/ handling/transport stress and early stage VHS. However mortality declined to $35-52 \%$ during the second 


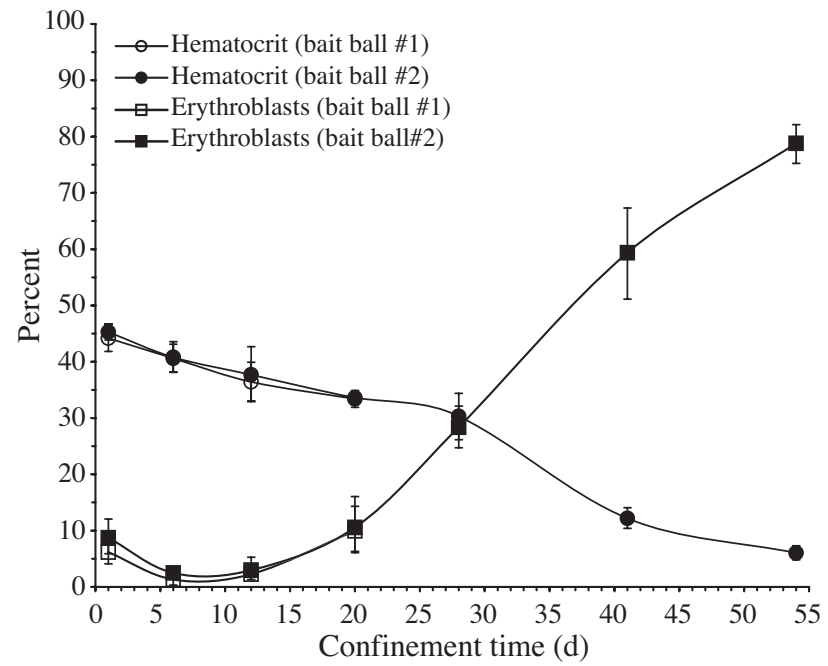

Fig. 3. Clupea pallasii. Blood changes during VHS and VEN epidemics. Erythroblast curves indicate percentage of immature erythrocytes among all blood cells. Data represent proportions corresponding to means of arcsine-transformed percentages in 3 replicate tanks; percent in each replicate was determined by sampling 10 fish tank $^{-1}$ each sampling date. (Means $\pm 2 \mathrm{SD} ; 95 \%$ confidence intervals)

week, and remained steady at 31 to $35 \%$ thereafter. All mortality among fish naturally infected with Ichthyophonus occurred within $3 \mathrm{wk}$ of confinement. Prevalence of ichthyophoniasis in the dead fish declined from $2.3 \%$ after $1 \mathrm{wk}$ to $0 \%$ after $4 \mathrm{wk}$ (Fig. 4 ). No further fish with ichthyophoniasis remained in the tanks after $20 \mathrm{~d}$, when the final 2 live fish demonstrating gross signs were removed during random sampling for VHS and VEN.

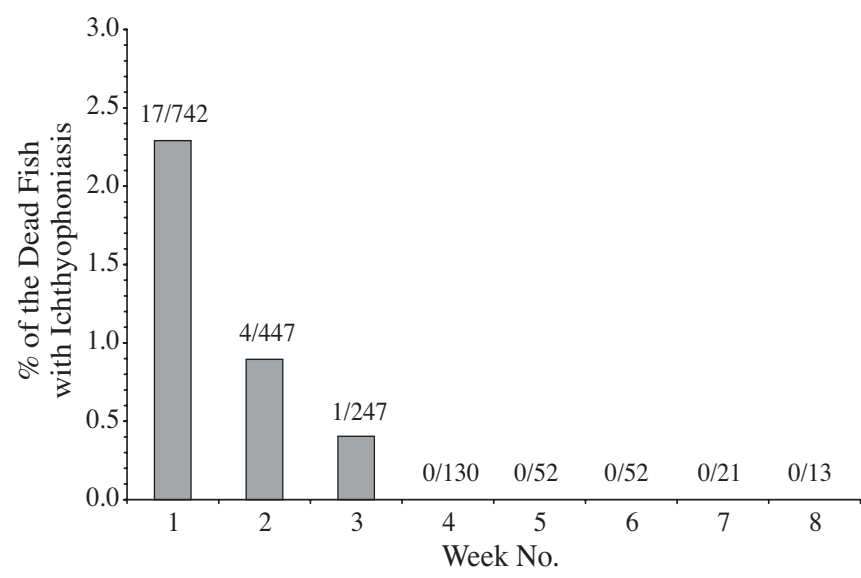

Fig. 4. Clupea pallasii. Ichthyophoniasis in fish that died during $54 \mathrm{~d}$ laboratory confinement. Fish were considered diseased when visible signs (black spots) were apparent on skin and Ichthyophonus was isolated from explant cultures. Data represent combined mortalities in all 6 replicates from both bait balls

\section{Virology of erythrocytic inclusions}

Erythrocytic inclusion bodies occurring after confinement of wild, juvenile herring were typical of those described for VEN, and challenges of specificpathogen-free herring demonstrated that the observed erythrocytic inclusions were not an unreported sign of VHS. Among specific-pathogen-free, laboratoryreared herring challenged with VHSV, a rapid epidemic ensued, characterized by weekly mortalities of 78,22 and $0 \%$ after Weeks 1 to 3, respectively. During the first week after challenge, VHSV tissue titers were $>6 \times 10^{7} \mathrm{pfu} \mathrm{g}^{-1}$ in pools of tissues from dead fish. However, erythrocytic inclusions did not occur in any ( 0 of 7 ) of the fish that survived for $22 \mathrm{~d}$ postchallenge, when the study was terminated. This contrasted with juvenile wild herring for which, $22 \mathrm{~d}$ after laboratory confinement and subsequent VHS outbreak, erythrocytic inclusions occurred in $>90 \%$ of erythrocytes among surviving cohorts (Fig. 2). Among SPF negative controls exposed to HBSS, cumulative mortality was $0 \%$, VHSV was not isolated, and erythrocytic inclusions were not detected in any survivors after $22 \mathrm{~d}$ (0 of 10).

Transmission electron micrographs of inclusioned erythrocytes demonstrated the presence of icosahedral-shaped virions with an ultrastructure typical of that described for erythrocytic necrosis virus (Dannevig \& Thorud 1999). Virions averaged $125.4 \mathrm{~nm}$ in diameter $(\mathrm{n}=10)$ and had an electron-dense core (Fig. 5). The virions were not necessarily associated with the cytoplasmic inclusions, generally appearing in clusters or singly throughout the cytoplasm; however, virion size and shape was similar to that reported for Atlantic herring Clupea harengus affected with VEN (Reno et al. 1978).

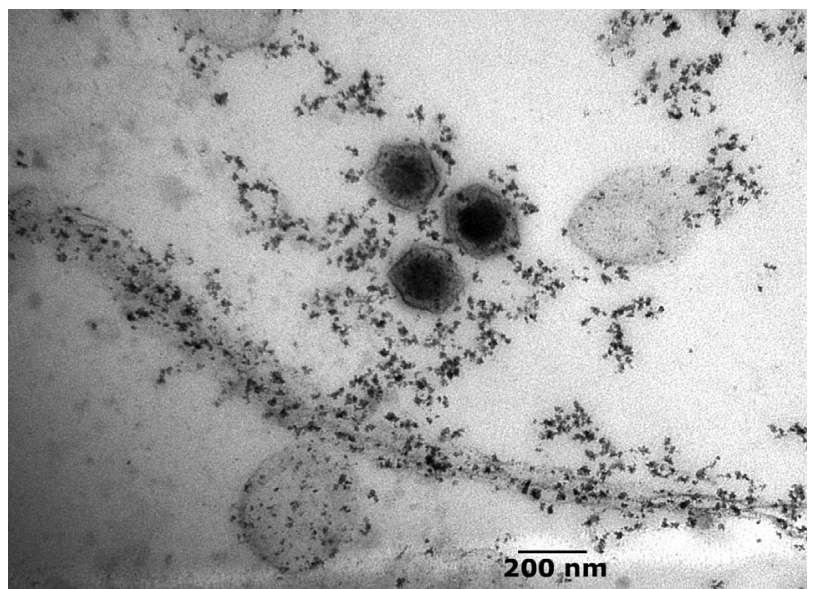

Fig. 5. Clupea pallasii. Transmission electron micrograph of virions within erythrocytes demonstrating cytoplasmic inclusions. Note icosahedral shape and electron-dense cores typical of iridoviruses 


\section{DISCUSSION}

Capture and laboratory confinement of wild, juvenile herring resulted in progression of 3 infectious diseases, namely VHS, VEN and ichthyophoniasis; however, the timing and progression of the 3 diseases differed, reflecting differences in essential epidemiological factors such as the level of carriers in the captured population, virulence of the causative agent, mode of transmission and rapidity of spread. The acute rhabdoviral disease VHS was observed initially and probably resulted from infections that spread among susceptible individuals quickly after capture from a relatively few active carriers. For example, Kocan et al. (2001) demonstrated that within minutes after capture and confinement of wild, juvenile Pacific herring in static transport tanks, shedding of endogenous virus by a small percentage of individuals results in a concentration of waterborne VHSV sufficient to initiate lethal infections in naïve Pacific herring (Kocan et al. 1997). Although the herring used in our studies were not assayed for VHS immediately after capture, the prevalence and intensity of infection in these populations at any given time point are typically very low (Hershberger et al. 1999, Kocan et al. 2001). Susceptible fish that became infected in confinement either died from VHS or mounted a protective immune response, clearing the infection and surviving as individuals that were later refractory to re-infection (Kocan et al. 2001).

The peak in VEN followed that of VHS, and unlike VHS where the outbreak subsided rapidly after the peak, the resulting chronic viremia persisted for $54 \mathrm{~d}$, at which time the study was terminated. Similar prolonged viremias of 3 to 4 mo occur in Atlantic cod infected with ENV (Reno et al. 1986). Intracellular infection of erythrocytes may offer protection from the host immune system and explain the prolonged viremia associated with ENV or other viruses with tropism for erythropoietic cells (Emmons 1985). While a nominally protective immune response sufficient to clear or suppress natural infections is likely to develop after exposure to ENV (MacMillan \& Mulcahy 1979), this response would be absent among naïve fish or might be overwhelmed in previously exposed individuals confronted with a high level of virus that probably occurs from viral shedding and concentration in laboratory tanks. As with VHSV, the initial carrier rate for ENV among wild fish is probably low, but sufficient to initiate waterborne infections that spread and intensify among captive individuals in a progressive, but less acute, manner. The resulting VEN then manifests as a suite of severe blood dyscrasias (Haney et al. 1992) including erythrocytopenia, possible lymphopenia, erythroblastosis and reduced hematocrits that can result in direct mortality, especially in situations requiring high levels of respiratory activity; however, predisposition to secondary pathogens or increased sensitivity to environmental perturbations are more typically observed (MacMillan et al. 1989).

Unlike the acute disease VHS or the more chronic condition VEN, the early mortality of Ichthyophonusinfected cohorts probably resulted from pre-existing, chronic infections that did not spread within the confined population, but which were activated or exacerbated by the multiple stressors associated with capture, transport, confinement and progression of concomitant viral diseases. For example, elevated levels of circulating glucocorticoids occur after fish capture and handling (Mazur \& Iwama 1993), and application of high levels of corticosteroids to fish chronically infected with Ichthyophonus results in progression to overt disease and mortality (Perry et al. 2004). Additionally, the health of infected cohorts was probably compromised from the onset, because Ichthyophonus-infected fish demonstrate reduced fitness compared to uninfected groups (Tierney \& Farrell 2004), probably reducing their probability of resisting or recovering from viral diseases.

Our results indicate the need for precaution when ascribing causation for epizootics in populations of wild Pacific herring. For example, episodic herring kills caused by VHS occur periodically in the eastern North Pacific (Meyers et al. 1999, Traxler et al. 1999, Hedrick et al. 2003). However, if a delay of several days occurs prior to investigation of a VHS-induced epidemic among herring, the survivors may have cleared the primary agent and a secondary outbreak of VEN may be inappropriately identified as the cause of the epizootic. This principle, although general for disease ecology, is likely to be host- and pathogenspecific. For example, VHS is endemic to populations of Pacific sandlance Ammodytes hexapterus in Puget Sound, where the epidemiology is very similar to that of juvenile herring (Kocan et al. 2001); however, confined wild Pacific sandlances do not develop erythrocytic inclusion bodies typical of VEN (P. Hershberger unpubl. data) like those observed in Pacific herring.

The results of this study illustrate the differences in disease ecology and possible synergistic effects of pathogens affecting marine fish as well as the impact of other stressors on the disease process. For example, we hypothesize that such synergistic effects may begin to explain historical reports of massive mortalities associated with Ichthyophonus, a pathogen that can persist in a host for long periods without initiating rapid disease or mortality. If a high percentage of a population were chronically infected with Ichthyophonus, as is currently the case with herring populations in the eastern North Pacific (Hershberger et al. 2002, Jones \& 
Dawe 2002), and exposure of these populations to multiple natural stressors and/or other endemic pathogens results in increased mortality among the Ichthyophonus-infected cohorts, as in our laboratory experiment, then the resulting increase in mortality may represent a major epidemic similar to those reported in Atlantic herring populations (Sindermann 1990, Rahimian \& Thulin 1996, McVicar 1999).

Acknowledgements. The authors acknowledge D. Elliott for interpretation of cellular degeneration in blood film preparations. G. Traxler and J. Richard provided VHSV isolates for the laboratory challenge studies. Preparation of samples for transmission electron microscopy was provided by C. Conway. Technical assistance was provided by Richard Hitchcock and pilot studies with VEN were performed by J. Hemplemann.

\section{LITERATURE CITED}

Batts WN, Winton JR (1989) Enhanced detection of infectious hematopoietic necrosis and other fish viruses by pretreatment of cell monolayers with polyethylene glycol. J Aquat Anim Health 1:284-290

Bernoth EM (2002) Third progress report on the research program into mass mortalities of pilchards in south Australian waters. Australia's Consultive Committee on Emerging Animal Diseases: Joint Pilchard Scientific Workgroup. p 1-15

Bozzola JJ, Russell LD (1992) Electron microscopy: principles and techniques for biologists. Jones \& Bartlett, Boston, MA

Criscione CD, Watral V, Whipps CM, Blouin MS, Jones SRM, Kent ML (2002) Ribosomal DNA sequences indicate isolated populations of Ichthyophonus hoferi in geographic sympatry in the north-eastern Pacific Ocean. J Fish Dis 25:575-582

Dannevig BH, Thorud KE (1999) Other viral diseases and agents of cold-water fish: infectious salmon anaemia, pancreas disease, and viral erythrocytic necrosis. In: Woo PTK, Bruno DW (eds) Fish diseases and disorders, Vol 3, Viral, bacterial, and fungal infections. CAB International Publishing, New York, p 149-175

Einer-Jensen K, Olesen NJ, Lorenzen N, Jørgensen PEV (1995) Use of the polymerase chain reaction (PCR) to differentiate serologically similar viral haemorrhagic septicaemia (VHS) virus isolates from Europe and America. Vet Res 26:464-469

Emmons RW (1985) An overview of Colorado tick fever. Prog Clin Biol Res 178:47-52

Evelyn TPT, Traxler GS (1978) Viral erythrocytic necrosis: natural occurrence in Pacific salmon and experimental transmission. J Fish Res Board Can 35:903-907

Gaughan DJ, Mitchell RW, Blight SJ (2000) Impact of mortality, possibly due to herpesvirus, on pilchard Sardinops sagax stocks along the south coast of Western Australia in 1998-1999. Mar Freshw Res 51:601-612

Halos D, Hart A, Hsu H, Hershberger P, Kocan R (2005) Ichthyophonus in Puget Sound rockfish, Sebastes emphaeus from the San Juan archipelago and Puget Sound, Washington, USA. J Aquat Anim Health 17: 222-227

Haney, DC, Hursh DA, Mix MC, Winton JR (1992) Physiological and hematological changes in chum salmon artificially infected with erythrocytic necrosis virus. J Aquat Anim Health 4:48-57

Harvell, D, Aronson R, Baron N, Connell J and 13 others (2004) The rising tide of ocean diseases: unsolved problems and research priorities. Front Ecol Environ 2:375-382

Hedrick RP, Batts WN, Yun S, Traxler GS, Kaufman J, Winton JR (2003) Host and geographic range extensions of the North American strain of viral hemorrhagic septicemia virus. Dis Aquat Org 55:211-220

Herr RA, Ajello L, Taylor JW, Arseculeratne SN, Mendoza L (1999) Phylogenetic analysis of Rhinosporidium seeberi's $18 S$ small subunit ribosomal DNA groups this pathogen among members of the protoctistan mesomycetozoa clade. J Clin Microbiol 37:2750-2754

Hershberger PK, Kocan RM, Elder NE, Meyers TR, Winton JR (1999) Epizootiology of viral hemorrhagic septicemia virus in Pacific herring from the spawn-on-kelp fishery in Prince William Sound, Alaska, USA. Dis Aquat Org 37:23-31

Hershberger PK, Stick K, Bui B, Carroll C and 7 others (2002) Incidence of Ichthyophonus hoferi in Puget Sound fishes and its increase with age of Pacific herring. J Aquat Anim Health 14:50-56

Hyatt AD, Hine PM, Jones JB, Whittington RJ, Kearns C, Wise TG, Crane MS, Williams LM (1997) Epizootic mortality in the pilchard Sardinops sagax neopilchardus in Australia and New Zealand in 1995. II. Identification of a herpesvirus within the gill epithelium. Dis Aquat Org 28:17-29

Jones JB, Hyatt AD, Hine PM, Whittington DA, Griffin DA, Bax NJ (1997) Special topic review: Australian pilchard mortalities. World J Microbiol Biotechnol 13:383-392

Jones SRM, Dawe SC (2002) Ichthyophonus hoferi Plehn \& Mulsow in British Columbia stocks of Pacific herring, Clupea pallasii Valenciennes, and its infectivity to chinook salmon, Oncorhynchus tschawytscha (Walbaum). J Fish Dis 25:415-421

Kocan R, Bradley M, Elder N, Meyers T, Batts W, Winton J (1997) North American strain of viral hemorrhagic septicemia virus is highly pathogenic for laboratory-reared Pacific herring. J Aquat Anim Health 9:279-290

Kocan RM, Hershberger P, Mehl T, Elder N, Bradley M, Wildermuth D, Stick K (1999) Pathogenicity of Ichthyophonus hoferi for laboratory-reared Pacific herring Clupea pallasii and its early appearance in wild Puget Sound herring. Dis Aquat Org 35:23-29

Kocan RM, Hershberger PK, Elder NE, Winton JR (2001) Epidemiology of viral hemorrhagic septicemia among juvenile Pacific herring and Pacific sand lances in Puget Sound, Washington. J Aquat Anim Health 13:77-85

MacMillan JR, Mulcahy D (1979) Artificial transmission to and susceptibility of Puget Sound fish to viral erythrocytic necrosis (VEN). J Fish Res Board Can 36:1097-1101

MacMillan JR, Mulcahy D, Landolt ML (1989) Cytopathology and coagulopathy associated with viral erythrocytic necrosis in chum salmon. J Aquat Anim Health 1:255-262

Marty GD, Freiberg EF, Meyers TR, Wilcock J, Farver TB, Hinton DE (1998) Viral hemorrhagic septicemia virus, Ichthyophonus hoferi, and other causes of morbidity in Pacific herring Clupea pallasii spawning in Prince William Sound, Alaska, USA. Dis Aquat Org 32:15-40

Mazur CF, Iwama GK (1993) Handling and crowding stress reduced number of plaque-forming cells in Atlantic salmon. J Aquat Anim Health 5:98-101

McVicar AH (1999) Ichthyophonus and related organisms. In: Woo PTK, Bruno DW (eds) Fish diseases and disorders, Vol 3, Viral, bacterial, and fungal infections. CAB International Publishing, New York, p 661-687

Mendoza L, Taylor JW, Ajello L (2002) The class mesomyce- 
tozoea: a heterogeneous group of microorganisms at the animal-fungal boundary. Annu Rev Microbiol 56:315-344

Meyers TR, Hauck AK, Blackenbeckler WD, Minicucci T (1986) First report of viral erythrocytic necrosis in Alaska, USA, associated with epizootic mortality in Pacific herring, Clupea harengus pallasii (Valenciennes). J Fish Dis 9:479-491

Meyers TR, Short S, Lipson K (1999) Isolation of the North American strain of viral hemorrhagic septicemia virus (VHSV) associated with epizootic mortality in two new host species of Alaskan marine fish. Dis Aquat Org 38: 81-86

Perry JA, Kocan RM, Winton JR, Hershberger PK (2004) High doses of corticosteroid suppress resistance to Ichthyophonus in starry flounder. J Aquat Anim Health 16:45-49

Ragan MA, Goggins CL, Cawthorn RJ, Cerenius L and 5 others (1996) A novel clade of protistan parasites near the animal-fungal divergence. Proc Natl Acad Sci USA 93: 11907-11912

Rahimian H, Thulin J (1996) Epizootiology of Ichthyophonus hoferi in herring populations off the Swedish west coast. Dis Aquat Org 27:187-195

Rand TG, White K, Cannone JJ, Gutell RR, Mwphy CA, Ragan MA (2000) Ichthyophonus irregularis sp. nov. from the yellowtail flounder Limanda ferruginea from the Nova Scotia shelf. Dis Aquat Org 41:31-36

Reno PW, Philippon-Fried M, Nicholson BL (1978) Ultrastructural studies of piscine erythrocytic necrosis (PEN) in Atlantic herring (Clupea harengis harengus). J Fish Res Board Can 35:148-154

Reno PW, Kleftis K, Sherburne SW, Nicholson B (1986) Experimental infection and pathogenesis of viral erythrocytic necrosis (VEN) in Atlantic cod, Gadus morhua. Can J Fish Aquat Sci 43:945-951

Editorial responsibility: Jo-Ann Leong,

Kaneohe, Hawaii, USA
Scott ME (1988) The impact of infection and disease on animal populations: implications for conservation biology. Conserv Biol 2:40-56

Sindermann C (1990) Principal diseases of marine fish and shellfish, 2nd edn, Vol 1. Diseases of marine fish. Academic Press, New York

Snow M, Bain N, Black J, Taupin V, Cunningham CO, King JA, Skall HF, Raynard RS (2004) Genetic population structure of marine viral haemorrhagic septicaemia virus (VHSV). Dis Aquat Org 61:11-21

Tierney KB, Farrell AP (2004) The relationship between fish health, metabolic rate, swimming performance, and recovery in return-run sockeye salmon, Oncorhynchus nerka (Walbaum). Fish Dis 27:663-671

Traxler GS, Keiser D, Richard J (1999) Mass mortality of pilchard and herring associated with viral hemorrhagic septicemia virus in British Columbia, Canada. Newsl Am Fish Soc Fish Health 27(4):3-4

Walker PJ, Benmansour A, Dietzgen R, Fang RX and 6 others (2000) Family Rhabdoviridae. In: Van Regenmortel MHV, Fauquet CM, Bishop DHL, Carstens EB and 7 others (eds) Virus taxonomy. Classification and nomenclature of viruses - Seventh Report of the International Committee on Taxonomy of Viruses. Academic Press, San Diego, CA, p 563-582

Ward TM, Hoedt F, McLeay L, Dimmlich WF and 5 others (2001) Effects of the 1995 and 1998 mass mortality events on the spawning biomas of sardine, Sardinops sagax, in South Australian waters. ICES J Mar Sci 58:865-875

Whittington RJ, Jones JB, Hine PM, Hyatt AD (1997) Epizootic mortality in the pilchard Sardinops sagax neopilchardus in Australia and New Zealand in 1995. I. Pathology and epizootiology. Dis Aquat Org 28:1-15

Submitted: October 6, 2005; Accepted: February 6, 2006 Proofs received from author(s): June 12, 2006 